\title{
The influence of variety and fertilization on the content of nitrates in parsley (Petroselinum ssp.)
}

\author{
Alma Rahimić*1 $\cdot$ Vedrana Komlen ${ }^{1}$ - Aleksandra Govedarica-Lučić ${ }^{2}$ \\ ${ }^{1}$ Džemal Bijedić University of Mostar, Agro Mediterranean Faculty, University Campus, 88104 Mostar, Bosnia and Herzegovina
} 2University of East Sarajevo, Faculty of Agriculture, Vuka Karadžića 30, Lukavica 71126, Bosnia and Herzegovina

\begin{abstract}
Summary: This paper presents the results of research on the impact of different varieties and fertilizers on the nitrate content in the leaf and root of parsley. In two-year research, three varieties of parsley were used and three variants of fertilization were applied (mineral fertilizers, organic and organo-mineral fertilizer) as well as a control variant. Nitrate content differed in the leaf and root. Depending on the investigated factors, their content in the leaf ranged from 55.60 to $426.09 \mathrm{mg} / \mathrm{kg}$ and in the root it ranged from 98.46 to $688.97 \mathrm{mg} / \mathrm{kg}$. The nitrate content in parsley leaf and root was significantly influenced by the variety and type of fertilizer. The variety "Domestic sawmills" accumulated the minimum nitrate content in the leaf and root of parsley. Mineral fertilization contributed to the accumulation of the highest content of harmful nitrates in the leaf and root of parsley.

Key words: fertilizers, leaf, nitrates, parsley, root, varieties
\end{abstract}

\section{Introduction}

Parsley (Petroselinum hortense) is a Mediterranean plant with a two-year biological cycle. It is a valuable vegetable grown for food, because of its beneficial characteristics. Both fresh and dried parsley are used in food, cosmetic and pharmaceutical industries, for production of spices, essential oils, and medication production as well (Lopez et al., 1999).

There are three types of parsley: flat leaves parsley (ssp. neapolitanum) and curly leaves parsley (ssp. crispum) which are grown because of their leaves, and turnip rooted parsley (ssp. tuberosum) grown because of its root. They are different in their morphology and chemical content, as well as in the content of essential oils (Petropoulus et al., 2004).

Parsley is a plant that needs a lot of additive nutrients for growth and root and leaves development, but on the other side, a lot of fertilizers, especially nitrogen, can badly damage human's health (Mansuroglu et al., 2011). Parsley belongs to a group of plants with a great amount of nitrates, because its leaves have characteristic of high accumulation of nitrates, which means that inappropriate fertilizer, especially nitrogen-rich, can cause an excessive amount of nitrates and other nitrogen compounds (Santamaria, 2006). Many different factors can influence the content of nitrate in plant. Breimer (1982) reported that higher content of nitrates in spinach was caused by the following factors: reduced soil, reduced intensity of

Corresponding author: alma.rahimic@unmo.ba light, and high temperatures. According to the same author, the content of nitrates grows with increase of potassium in the ground (less when $\mathrm{K}$ is in chloride form than in sulfate form), and it decreases with increase of soil $\mathrm{pH}$. A positive result is achieved by using manure.

Fertilization of vegetables, especially with nitrogen fertilizer, and intensity of light are the most important factors that influence the content of nitrates in vegetables (Cantliffe, 1973). The content of nitrates varies in different parts of the plant (Anjana et al., 2006; Santamaria et al., 1999). Accumulation of nitrates also depends on the amount and kind of nutrients in the soil, from the moment of application, amount and content of used fertilizers (Zhou et al., 2000). pH value of soil has the most important role in the accumulation of nitrates in the plant. Maintaining the level of $\mathrm{pH}$ from $6.5-7.5$ is one of needed factors in order to reduce the content of nitrates in the plants (Sady, 2000). Optimal pH reaction for cultivation of parsley is in the interval between 6 and 8 (Đurovka, 2008).

The aim of this study was to determine how the kind of fertilizer affects the content of harmful nitrates in the leaf and root of parsley.

\section{Material and Method}

The content of nitrates in leaves and root of parsley was studied during two vegetation periods (2013 and 2014) in Bijelo Polje, the north suburb of Mostar, in randomized block in 4 repetitions, on $1 \mathrm{~m}^{2}$ parcel. Three parsley varieties were used and three types of fertilizers (mineral, organic and organo-mineral fertilizer) with a 
control variant. The following varieties of parsley were used: „Domestic sawmills“- sawmill type ( $P$. hortense ssp. neapolitanum), „Mooskrause“ - curly leaves type $(P$. bortense ssp. crispum), „Berlin semi-long type“ - root type (P. hortense ssp. tuberosum).

There were three fertilization variants in the trial (mineral, organic and organo-mineral fertilizer) and a control variant. For mineral fertilization as a starting fertilizer, a permanently complex fertilizer NPK 8:16:24 was applied in the quantity of $720 \mathrm{~kg} / \mathrm{ha}$ and KAN $(27 \% \mathrm{~N})$ fertilizer in the amount of $170 \mathrm{~kg} / \mathrm{ha}$ to supplement the required quantity N. For organic fertilization sheep manure was used, which was applied in the basic fertilization in the amount of $20 \mathrm{t} / \mathrm{h}$. Organo-mineral fertilizer was also applied in basic fertilization in the recommended amount for vegetable crops of $1 \mathrm{t} /$ ha. Phenix fertilizer was used as an organomineral fertilizer. It is a combination of organic and mineral fertilizers whose NPK values are 6: 8: $15+$ $\mathrm{MgO}$. Quantities of applied fertilizers were within the ranges recommended by different authors (Lešić et al., 2004; Lazić et al., 2013). The seed was sown in early March in rows at a distance of $20 \mathrm{~cm}$ and the rate of sowing $3 \mathrm{~g} / \mathrm{m}^{2}$. Before setting up the experiments, soil samples were taken from the $0-30 \mathrm{~cm}$ depth for chemical analyses. According to the results of soil analyses, the $\mathrm{pH}$ value of the soil determined in water had a slight alkaline reaction (7.56) and in $\mathrm{KCl}$ poorly acidic to neutral (6.76). The total of $\mathrm{N}$ content $0.21 \%$ indicated that the soil was well-supplied with nitrogen. According to the content of available $\mathrm{P}_{2} \mathrm{O}_{5} \quad(8.20$ $\mathrm{mg} / 100 \mathrm{~g}$ ), the soil sample was poorly supplied with phosphorus (3rd class). $\mathrm{K}_{2} \mathrm{O}$ content was $16.80 \mathrm{mg} / 100$ $\mathrm{g}$ which corresponds to good supply (2nd class). The content of humus in \% was 1.60 , which indicates that the soil had low humus content.

Samples for the analysis of plant material were taken after the first cuttings of the leaf, which was in June and the roots were removed in October.

Spectrophotometric - colorimetric method was used to determine the nitrate content. The method is based on nitrate reduction in nitrite, using a reducing agent of hydrazine sulphate. The enriched nitrate in reaction with the colouring reagent which contains sulphanilamide builds a complex pink compound. The pink colour intensity is the indicator of nitrate content in the material and it is measured with a spectrophotometer at a wavelength of $540 \mathrm{~nm}$. The concentration of $\mathrm{NO}_{3}$ in the test sample is calculated by the formula:

$$
\mathrm{mgNO}_{3}-/ \mathrm{kg}=\mathrm{cxVxR} / \mathrm{n}
$$

And it follows as:

$\mathrm{C}$ - concentration of $\mathrm{NO}_{3}{ }^{-}$read from the curve $\left(\mu \mathrm{g} / \mathrm{cm}^{3}\right)$, $\mathrm{V}$ - total sample volume in $\mathrm{cm}^{3}$,

$\mathrm{R}$ - dilution factor

$\mathrm{N}$ - sample weight $(\mathrm{g})$
Two-factorial analysis of variance was used for data processing, and for testing significances difference between the middles the LSD test.

\section{Results and Discussion}

In both years of our research, the higher nitrate content was in the root of parsley compared to the content of the leaf. Depending on the factors investigation, their content in the leaves ranged from 55.60 to $426.09 \mathrm{mg} / \mathrm{kg}$ and in the root from 98.46 to 688.97.

The content of nitrates varied in different plant parts. Most nitrates are accumulated in the leaf petioles and leaves, and the least in fruit and seeds (Santamaria et al., 1999).

The content of nitrates in the leaf in 2013 did not differ significantly between the varieties in the study, while in 2014 the "Mooskrause" had significantly higher level of nitrates in the leaf compared to the other two varieties. Similar to our results, Pasikowska et al. (2002) reported a greater tendency of the curly parsley type which belongs to "Mooskrause" to accumulate nitrates than the flat leafed type of parsley. Similar results were also obtained by Kolota (2011) where the nitrate content in the fresh leaf ranged from 193 to $443 \mathrm{mg} / \mathrm{kg}$ in the curly type of parsley which belongs to the "Mooskrause" and to the flat leafed type of 190 to 274 $\mathrm{mg} / \mathrm{kg}$ to which belongs the "Domestic sawmills". Beside presenting the two-year average, there was significant difference between nitrate content in leafs of the same parsley varieties but in different years, while the nitrate content in the roots of the same varieties of parsley did not differ between two years.

The content of nitrates in the leaves of parsley in mineral fertilization was significantly higher than in organic fertilization. Mineral fertilization of parsley in both study years caused the accumulation of the highest content of nitrate in the leaf of parsley. Compared with organic fertilizers, mineral fertilizers are characterized by higher concentrations in nutrients. Also, with the application of mineral fertilizers nutrients elements are incorporated into the soil into a directly available form for plants. Easily soluble mineral fertilizers which are absorbed rapidly into the plant usually lead to higher nitrate levels (Rembialkowska, 2007).

In both years the leaf of parsley in the mineral variant had a significantly higher content of nitrates compared to other variants, which mutually did not differ significantly (Table 1). The same was reported in the three-year study by Pavlou et al. (2007), who investigated the influence of different doses of organic and mineral fertilizers on the growth, development and accumulation of nitrates in lettuce. The highest content of nitrates in all three years was found in lettuce fertilized with medium and maximum doses of mineral fertilizer, statistically significantly higher in comparison 
Table 1. The influence of variety and fertilizer on the content of nitrates in the parsley leafs $(\mathrm{mg} / \mathrm{kg})$

\begin{tabular}{|c|c|c|c|c|c|}
\hline Year & Fertilizer* & Variety* & & & Average \\
\hline \multirow{6}{*}{2013} & & $\mathrm{~A}$ & $\mathrm{~B}$ & $\mathrm{C}$ & \\
\hline & 1 & 60.32 & 86.06 & 55.60 & $67.33^{b}$ \\
\hline & 2 & 86.95 & 123.43 & 75.79 & $95.39 \mathrm{~b}$ \\
\hline & 3 & 64.16 & 62.69 & 74.78 & $67.21^{\mathrm{b}}$ \\
\hline & 4 & 192.13 & 145.78 & 97.37 & $145.09^{a}$ \\
\hline & Average & $100.89 \mathrm{~ns}$ & $104.49 \mathrm{~ns}$ & $75.88^{\mathrm{ns}}$ & \\
\hline \multirow{3}{*}{$\begin{array}{l}\mathrm{LSD}_{0.05} \\
\mathrm{LSD}_{0.01}\end{array}$} & & & Fertilizer & & Variety \\
\hline & & & 45.35 & & 52.37 \\
\hline & & & 61.79 & & 71.35 \\
\hline \multirow[t]{5}{*}{2014} & 1 & 94.12 & 207.43 & 162.13 & $154.56^{b}$ \\
\hline & 2 & 200.05 & 102.03 & 143.70 & $148.59 \mathrm{~b}$ \\
\hline & 3 & 202.38 & 124.03 & 203.33 & $176.58^{b}$ \\
\hline & 4 & 193.35 & 259.70 & 426.09 & $293.05^{\mathrm{a}}$ \\
\hline & Average & $172.47^{b}$ & $173.30^{\mathrm{b}}$ & $233.81^{\mathrm{a}}$ & \\
\hline \multirow{3}{*}{$\begin{array}{l}\mathrm{LSD}_{0.05} \\
\mathrm{LSD}_{0.01}\end{array}$} & & & Fertilizer & & Variety \\
\hline & & & 50.01 & & 57.75 \\
\hline & & & 68.13 & & 78.68 \\
\hline Two-year & 1 & 77.22 & 146.74 & 108.86 & 110.94 \\
\hline \multirow[t]{4}{*}{ average } & 2 & 143.5 & 112.73 & 109.74 & 121.99 \\
\hline & 3 & 133.27 & 93.36 & 139.05 & 121.89 \\
\hline & 4 & 192.74 & 202.74 & 261.73 & 219.07 \\
\hline & Average & 136.68 & 138.89 & 154.84 & \\
\hline
\end{tabular}

to organic variants and control variant. Vegetables fertilized with organic fertilizers had a lower content of nitrates compared to vegetables fertilized with mineral fertilizers (Raupp, 1996). Ubavić et al. (2002) stated that in natural, field conditions the content of nitrates in vegetables can be reduced by the production technology that is primarily based on the application of organic fertilizers.

Rembialkowska et al. (2012) compared the nitrate content in cabbage, tomato, salad, parsley, carrots, celery, and Chinese cabbage in organic and conventional method of cultivation. They concluded that their content in conventional cultivation was higher by $148.39 \%$ than in organic cultivation.

The investigated factors, variety and type of fertilization significantly influenced the content of nitrates in the root of the parsley. The highest nitrate content in the root of parsley in both trial years was found in "Mooskrause", significantly more than in "Domestic sawmills", while the difference in the nitrate content between the varieties "Mooskrause" and "Berlin semi-long" was not significant in both trial years. The content of nitrates can vary between different plant species, varieties and cultivars of the same species (Anjana et al., 2006; Grzebelus \& Baranski, 2001).

In both trial years, the highest nitrate content in parsley root was found in parsley fertilized with mineral fertilizer, significantly more than the other variants. Although the content of nitrate in the roots of parsley in 2013 was higher in mineral fertilization (441.16 $\mathrm{mg} / \mathrm{kg}$ ) compared to the control variant
(344.92 $\mathrm{mg} / \mathrm{kg}$ ), this difference was not significant. Boček et al. (2008) investigated the influence of organic, organo-mineral and mineral fertilizers on the yield and quality of tomato for processing and found that the highest nitrate content was in the control variant and the lowest in mineral fertilization.

In both years of research, the lowest nitrate content in the root was found in organic variant of fertilization, which did not differ significantly from organo-mineral one. The control variant had significantly higher nitrate content of both of these variants. Organic fertilizers contain nitrogen bound to organic material from which it is slowly released (Benbrook et al., 2008). With the use of organic fertilizers, the content of nitrate is lower even at higher fertilizer levels (Siti Aishah et al., 2012). Breimer (1982) suggests that manure fertilizer affects the reduction of nitrate content as evidenced in these studies.

Szopińska \& Gawęda (2013) received higher nitrate content in red beet grown in conventional breeding, somewhat smaller in the integral, while the lowest nitrate content was recorded in organically cultivated red beet. Organic production of nitrate content is less than 50\% (Lazić et al., 2013).

Different authors state different values of nitrate content in the root of parsley. According to Pokluda (2003), the content of nitrate in the root of parsley ranges from 113 to $617 \mathrm{mg} / \mathrm{kg}$; Bakowski et al. (1994) quoted values of 79 to $266 \mathrm{mg} / \mathrm{kg}$; Rumpel \& Kaniszewski (1994) from 154-290 mg/kg; Prugar \& Prugarova (1985) 40-1657 mg/kg. 
Table 2. The influence of variety and fertilizer on the content of nitrates in the parsley root $(\mathrm{mg} / \mathrm{kg})$

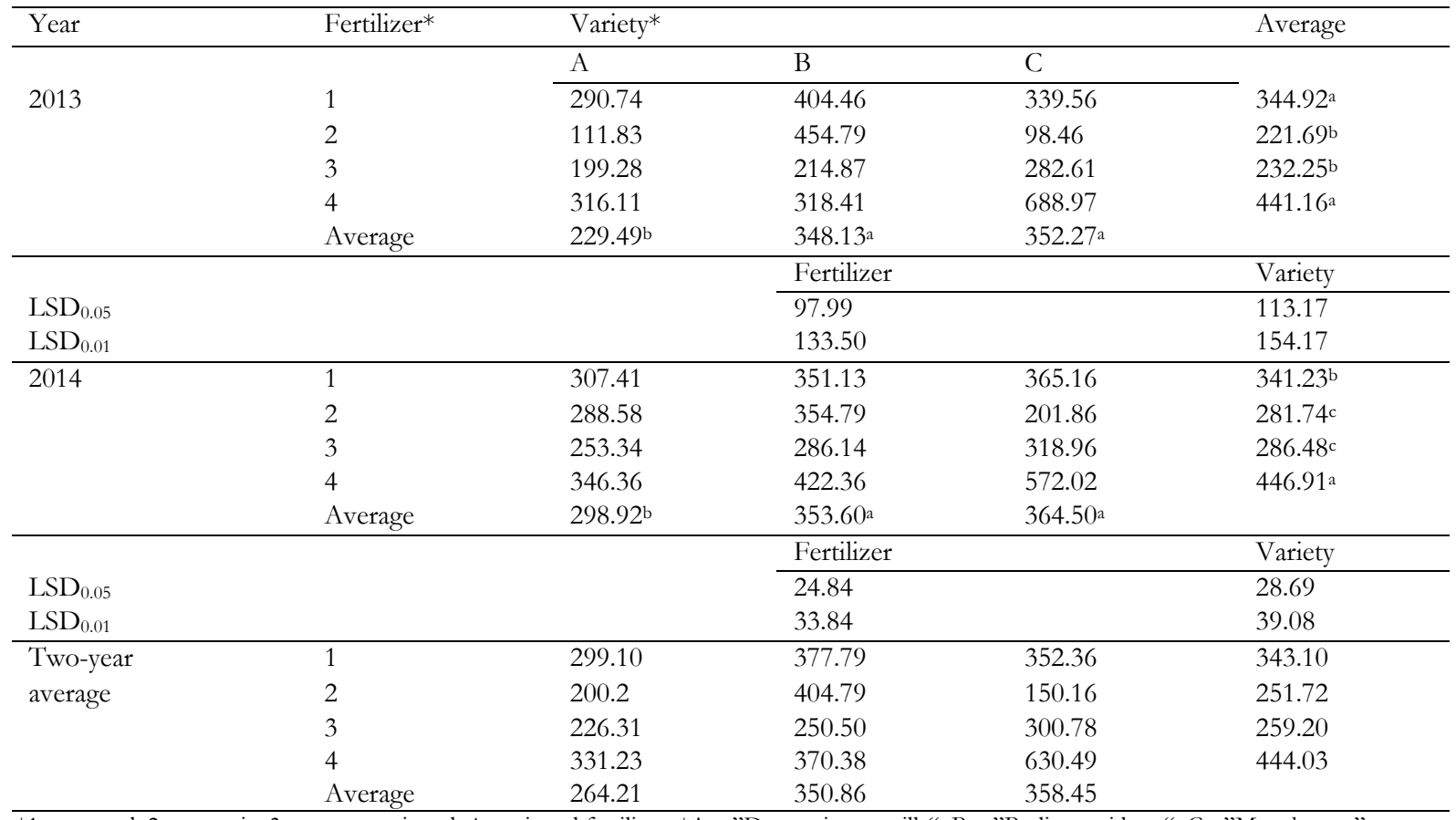

*1 - control, 2 - organic, 3 - organo-mineral, 4 - mineral fertilizer. *A - "Domestic sawmills“, B - "Berlin semi long“, C - "Mooskrause".

All three varieties of parsley in leaf and root accumulated more nitrates in 2014 than in 2013. During the vegetation period in 2014 there were more cloudy days and rainfall, and medium air temperatures were lower. In the absence of light and lower temperatures, nitrate content in vegetables increases, especially for varieties prone to such accumulation (Kosović, 1989). The influence of climatic factors on the accumulation of nitrates in plant tissue was studied by Grzebelus \& Baranski (2001), who found that the nitrate content was lower in the year with higher rainfall, which is contrary to our results. However, in a warm and humid year, increased nitrate accumulation is possible, regardless of whether the nitrogen originates from organic or mineral source (Custic et al., 2003). Higher nitrate content in 2014 can be explained by the fact that in 2014 there was a higher number of cloudy days and lower light intensity. Breimer (1982) points out that the lack of light and reduced light intensity contribute to a greater accumulation of nitrates in the leaves of leafy vegetables.

\section{Conclusions}

In both years of our study, the higher nitrate content was in the root of parsley than in the leaf. The content of nitrates in the leaf and root of parsley was significantly influenced by the variety and type of fertilizer. The variety "Mooskrause" showed the highest tendency to accumulate harmful nitrates in the leaf and root of parsley. The content of nitrate in the leaf and root was significantly higher in mineral fertilizer variation compared to control and other fertilization variants in both years. The content of nitrates differed considerably depending on the year of the study, which means that the nitrate content in the leaf and root of parsley was influenced by the climatic factors because the values of the basic climatic parameters differed in years of research. All three varieties of parsley in the leaf and root accumulated more nitrates in 2014 than in 2013.

\section{References}

Anjana, Umar S., Iqbal M., Abrol Y.P. (2006). Are nitrate concentrations in leafy vegetables within safe limits? Proceedings of the Workshop on Nitrogen in Environment, Industry and Agriculture, New Delhi, India, 22, 81-84.

Bakowski, J., Michalik, H., Umiecka L. (1994). Wplyw terminu siewu i zbioru na jakosc pietruszki korzeniowej i jej prezechowanie. Biul. Warz., 41, 157-167.

Benbrook, C., Zhao, X., Yanez, J., Davies, N., Andrews, P. (2008). New evidence confirms the nutritional superiority of plant-based organic foods. https://organic-center.org

Boček, B., Maly, I., Patočkova, Š. (2008). Yield and quality of bush processing tomatoes fertilized with dried organic and organomineral fertilizers. Acta Universitatis Agriculturae et Silviculturae Mendelianae Brunensis, 56(2), 31-38.

Breimer, T. (1982). Enviromental factors and cultural measures affecting the nitrate content in spinach. Nutrient Cycling in Agroecosystems, 3(3).

Cantliffe D.J. (1973). Nitrate accumulation in table beets and spinach as affected by nitrogen, phosphorus, and potassium nutrition and light intensity. Agron. J. 65, 563-565.

Custic, M., Poljak, M., Coga, L., Cosic, T., Toth, N., Pecina, M. (2003): The influence of organic and mineral fertilization on nutrient status, nitrate accumulation, and yield of head chicory. Plant Soil Environ, 49, 218-222. 
Grzebelus D., Baranski R. (2001). Identification of accessions showing low nitrate accumulation in a germplasm collection of garden beet. Acta Hortic, 563, 253-255.

Đurovka, M. (2008). Gajenje povría na otvorenom polju. Novi Sad: Poljoprivredni fakultet Novi Sad.

Kolota, E. (2011). Yield and quality of Leafy parsley as affected by the nitrogen fertilization. Acta Sci. Pol., Hortorum Cultus 10(3), 145 154.

Kosović, N. (1989). Uticaj rokova sadnje i đubrenja na prinos $i$ kvalitet salate u plastenickoj proizvodnji. Novi Sad: Poljoprivredni fakultet Novi Sad.

Lazić, B., Ilić, Z.S., Đurovka, M. (2013). Organska proizvodnja povría. Sremska Kamenica.: Centar za organsku proizvodnju, Selenča Univerzitet EDUKONS.

Lešić, R., Borošić, J., Butorac, I., Herak-Čustić, M., Poljak, M., Romić, D. (2004). Povríarstvo, Čakovec: Zrinski.

Lopez, M., Shancez - Mendoza, I., Ochoa-Alejo, N. (1999). Coparative study of volatile components and fatty acids of plants and in vitro cultures of parsley (Petroselinum cripsum Mill). J Agric Food Chem 47(8), 3292-3296.

Mansuroglu, S., G., Bozkurt, S., Telli, S., Uygur, V. (2011). Nitrate, nitrite and chlorophyll contents of parsley irrigated with different water levels of mini sprinkler irrigation under different amounts of nitrogen Ffertilizers. Journal of Cell and Plant Sciences 2(3), 1-8.

Pasikowska, R., Dabeowska, B., Capecka, E. (2002). The effect nitrogen fertilization rate on the yield and quality ot two cultivars of parsley Petroselinum sativum L ssp. cryspum in different soil types. Folia Hort, 14(1), 177-185.

Pavlou, G.C., Constantinos D. E., Kavvadias, V.A. (2007). Effect of organic and inorganic fertilizers applied during successive crop seasons on growth and nitrate accumulation in lettuce. Scientia Horticulturae, 111(4), 319-325.

Petropoulos, S., Daferera, D., Akoumianakis, C., Passam, H., Polissiou, M. (2004). The effect of sowing date and growth stage on the essential oil composition of three types of parsley
(Petroselinum crispum). Journal of the Science of Food and Agriculture, 84, 1606-1610.

Pokluda, R. (2003). Comparison of selected characteristics of root parsley (Petroselinum crispum conv. radicosum (Alef.) Danert) cultivars. Hort. Sci. (Prague) 30, (2), 67-72.

Prugar, J., Prugarova, A. (1985). Dusicnany v zelenine. Priroda, Bratislava, 150.

Raupp, J. (1996). Fertilization effects on product quality and examination of parameters and methods for quality assessment, in: Raupp J. (Ed.), Quality of plant products grown with manure fertilization. Darmstadt, 9, 44-48.

Rembialkowska, E. (2007). Quality of plant products from organic agriculture. J. Sci. Food Agric. 87, 2757-2762.

Rembialkowska, E., Zalecka, A., Badowski, M., Ploeger, A. (2012). The Quality of Organically Produced Food. http:// dx.doi.org/10.5772/54525, 65-93.

Rumpel, J., Kanisyewski, S. (1994). Influence of nitrogen fertilization on yield and nitrate nitrogen content of turnip-rooted parsley. Acta. Hort. 371, 413-416.

Sady, W. (2000). Nawozenie warzyw polowych. Wydawnictwo Plantpress, Krakow, 47-52.

Santamaria, P. (2006). Nitrate in vegetables: toxicity, content, intake and EC regulation. J. Sci. Food Agr. 86, 10-17.

Santamaria, P., Elia, A., Serio, F., Todaro, E. (1999). A survey of nitrate and oxalate content in retail fresh vegetables. J. Sci. Food Agr. 79, 1882-1888.

Siti Aishah, H., Salumiah, M., Umi Kalsom, Y., Phebe, D., Puteri Edaroyati Megat W. (2012). Nitrate, ascorbic acid, mineral and antioxidant activities of Cosmos caudatus in response to organic and mineral-based fertilizer rates. Molecules, 17, 7843-7853.

Szopinska, A.A., Gaweda, M. (2013). Comparison of yield and quality of red beet roots cultivated using conventional, integrated and organic method. Journal of Horticultural Research, 21(1), 107-114.

Zhou, Z.Y., Wang, M.J., Wang, J.S. (2000). Nitrate and nitrite contamination in vegetables in China. Food Rev. Int. 16, 61-76.

\section{Uticaj sorte i đubrenja na sadržaj nitrata u peršunu (Petroselinum ssp.)}

\section{Alma Rahimić · Vedrana Komlen · Aleksandra Govedarica-Lučić}

Sažetak: U ovom radu predstavljeni su rezultati istraživanja o uticaju različitih sorti i đubriva na sadržaj nitrata u listu i korenu peršuna. U dvogodišnjem ogledu korištene su tri sorte peršuna i primenjene tri varijante đubrenja (mineralno, organsko i organo-mineralno) i kontrolna varijanta. Sadržaj nitrata razlikovao se u listu i korenu. U zavisnosti od faktora ispitivanja njihov sadržaj u listu kretao se od 55,60 do 426,09 mg/kg, a u korenu od 98,46 do $688,97 \mathrm{mg} / \mathrm{kg}$. Na sadržaj nistrata u listu i korenu peršuna značajno su uticali sorta i vrsta đubriva. Sorta „Domaći lišćar“ akumulirala je najmanji sadržaj nitrata u listu i korenu peršuna. Mineralno đubrivo doprinelo je nakupljanju najvećeg sadržaja štetnih nitrata u listu i korenu peršuna.

Ključne riječi: đubrivo, koren, list, nitrati, peršun, sorte 